Lex Et Societatis Vol. VIII/No. 2/Apr-Jun/2020

\section{KAJIAN HUKUM INTERNASIONAL TERHADAP PELAKSANAAN HUKUMAN MATI WARGA NEGARA INDONESIA DI NEGARA ASING (Kasus Eksekusi Mati Tuti Tursilawati Tenaga Kerja Indonesia di Arab Saudi) ${ }^{1}$ Oleh : Juviella Natali Christi Makatita²}

\begin{abstract}
ABSTRAK
Tujuan dilakukannya penelitian yakni untuk mengetahui bagaimana Implementasi Hukum Internasional terhadap pelaksanaan hukuman mati dan bagaimana Tanggung jawab Negara Indonesia terhadap pelaksanaan hukuman mati Tuti Tursilawati di Arab Saudi dikaitkan dengan Hukum Internasional di mana dengan metode penelitian hukum normatif disimpulkan bahwa:
\end{abstract} 1. Dalam perjuangan melindungi hak-hak asasi manusia, hukum internasional sudah mengupayakan penghapusan hukuman mati yang masih saja diterapkan di berbagai Negara. Upaya perlindungan Hak Asasi Manusia ini dapat dilihat dari usaha-usaha penghapusan hukuman mati oleh hukum internasional yang dituangkan dalam berbagai instrumen hukum internasional dan dalam statute-statutta Mahkamah Internasional. Walaupun instrumen-instrumen hukum ini tidak secara eksplisit melarang hukuman mati, tetapi bersamaan dengan beberapa additional protocols yang secara tegas melarang hukuman mati, hukum hak asasi manusia internasional telah menunjukkan konsistensi dalam tujuan implisit yaitu mewujudkan penghapusan total di kemudian hari. 2. Pelaksanaan hukuman mati terhadap Tuti Tursilawati merupakan tanggung jawab Negara Indonesia. Pemerintah Indonesia sudah berusaha untuk melakukan perlindungan bagi warga negaranya. Hal ini merupakan kewajiban yang harus dipenuhi oleh Negara Indonesia, berlaku di mana pun warga negaranya berada. Pemerintah Indonesia juga sudah melayangkan protes kepada pemerintah Arab Saudi karena telah mengeksekusi Tuti Tursilawati tanpa pemberitahuan. Hal ini menggerakkan pemerintah Indonesia yang dengan segera meminta Arab Saudi untuk menandatangani perjanjian Mandatory Consular Notification.

\footnotetext{
${ }^{1}$ Artikel Skripsi. Dosen Pembimbing: Michael Nainggolan, S.H, M.H, DEA; Dr. Youla O. Aguw, S.H, M.H

2 Mahasiswa pada Fakultas Hukum Unsrat, NIM. 16071101228
}

Kata kunci: hukuman mati; hukum internasional;

\section{PENDAHULUAN}

\section{A. Latar Belakang}

Hal yang sangat kontroversial mengenai Hak Asasi Manusia antara lain yaitu tentang hukuman mati. Pokok-pokok isi Kovenan Internasional tentang Hak-hak Sipil dan Politik memuat tentang setiap manusia memiliki hak untuk hidup. Hak ini harus dilindungi oleh hukum. Perkembangan mengenai hak asasi ini mencapai juga kepada hak-hak bagi warga asing yang sedang berada di luar teritorial negara asalnya. Warga asing di suatu negara mendapatkan perlindungan melalui Konvensi Wina 1963 mengenai hubungan konsuler dan Konvensi Wina 1961 mengenai hubungan diplomatik. Warga asing harus diperlakukan dengan baik sama seperti perlakuan yang diberikan kepada warga negara asli di negara tersebut. $^{3}$

\section{B. Rumusan Masalah}

1. Bagaimana Implementasi Hukum Internasional terhadap pelaksanaan hukuman mati?

2. Bagaimana Tanggung jawab Negara Indonesia terhadap pelaksanaan hukuman mati Tuti Tursilawati di Arab Saudi dikaitkan dengan Hukum Internasional?

\section{Metode Penelitian}

Metode penelitian yang digunakan pada penulisian ini adalah Metode penelitian yuridis normative.

\section{PEMBAHASAN}

\section{A. Implementasi Hukum Internasional} Terhadap Pelaksanaan Hukuman Mati

Pemberian hukuman mati masih menjadi pro dan kontra di masyarakat dunia internasional, hal ini dikarenakan pemberian sanksi tersebut dianggap merampas hak untuk hidup seseorang. Sedangkan, jika dilihat dari kejahatan yang dilakukan, pemberian hukuman mati bisa saja merupakan langkah yang adil atau setimpal sebagai tebusan atas tindakan pelaku.

\footnotetext{
3 Martin Dixon, Textbook on International Law, 6th ed.,
} (United States: Oxford University Press, 2007) hal. 243 
Pada masa sekitar abad ke -18 dan 19, timbul kesadaran atas hak-hak asasi manusia yang salah satu diantaranya adalah hak untuk hidup. Perjuangan untuk melindungi hak-hak asasi manusia mencapai puncak pada abad ke 20. Deklarasi-deklarasi dan konvensi internasional serta seruan-seruan hak-hak asasi manusia mulai bermunculan baik yang diprakarsai oleh lembaga-lembaga internasional seperti PBB dan organ-organnya maupun oleh negara-negara secara kolektif dan individual. ${ }^{4}$

Norma hukum Internasional sedikit banyak menyinggung tentang pemberian hukuman mati. Dalam instrument HAM Internasional, Universal Declaration of Human Rights dan International Covenant on Civil and Political Rigths memuat larangan-larangan yang menolak adanya pelaksanaan hukuman mati. Sedangkan dalam instrumen hukum internasional, dimana berbagai Negara menolak adanya pelaksanaan hukuman mati terlihat dalam statuta-statuta Mahkamah Kejahatan Internasional yang hendak kita kaji yaitu ICTY (International Criminal Tribunal for the former Yugoslavia), ICTR (International Criminal Tribunal for Rwanda), dan ICC (International Criminal Court).

Kewajiban untuk memajukan penghargaan dan ketaatan menjalankan hak-hak asasi manusia ini harus dipenuhi oleh semua anggota Perserikatan Bangsa-bangsa, sebagaimana seperti yang telah mereka setujui.

a) Hukuman Mati Menurut Universal

Declaration of Human Rights

Pemberian hukuman mati terhadap seseorang ini di atur dalam Universal Declaration of Human Rights pada Pasal 3 "Everyone has the right to life, liberty and security of person" (Setiap orang berhak atas kehidupan, kebebasan, dan keselamatan sebagai individu). ${ }^{5}$

Bentuk yang paling ekstrim dari pelanggaran hak untuk hidup ini ialah pembunuhan atau melukai jasmani atau rohani dari seseorang ataupun kelompok Hukuman mati yang dengan maksud untuk membinasakan seluruhnya atau sebagian, suatu bangsa, suku bangsa, rasa atau

\footnotetext{
4 I Wayan Parthiana, Ekstradisi dalam Hukum Internasional dan Hukum Nasional, (Bandung: Penerbit Alumni, 1983), hal. 100.

5 Pasal 3 Universal Declaration of Human Rights
}

agama ini jelas telah melanggar pasal ini, dimana orang yang dijatuhi hukuman mati telah dirampas kehidupannya, kemerdekaannya, keamanan pribadinya. Bagaimanapun juga, hukuman mati adalah hukuman yang sangat melanggar hak untuk hidup bagi manusia sebagai makluk ciptaan Tuhan. Di samping pengaturan tentang hak dasar yaitu hak untuk hidup yang diatur dalam UDHR tersebut, yang dalam hal ini dihubungkan dengan hukuman mati, terdapat pengecualian terhadap pelaksanaan perlindungan hak untuk hidup yaitu dengan adanya pemahaman mendalam terhadap derogable rights/hak privasi, dalam hal yang pertama "a public emergency which treatens the life of nation" (keadaan darurat public yang mengancam kehidupan bangsa) dapat dijadikan dasar untuk membatasi pelaksanaan hak-hak kebebasan dasar, dengan syarat bahwa kondisi keadaan darurat (public emergency) tersebut harus diumumkan secara resmi (be officially proclaimed), bersifat terbatas serta tidak boleh diskriminatif. (Muladi, 2004 : 101).

Dapat dilihat banyak orang yang telah dijatuhi hukuman mati, antara lain koruptor di Cina, Saddam Hussein, ataupun lainnya. Namun seperti kasus Rwanda dan Yugoslavia pelaku pelanggaran HAM hanya diganjar dengan hukuman maksimal pidana seumur hidup, karena 42 hukuman mati di jaman modern ini mulai ditinggalkan oleh negara-negara di dunia, meskipun masih ada beberapa negara yang masih melaksanakannya dengan berbagai cara. ${ }^{6}$ Termasuk pemberian hukuman mati untuk Tuti Tursilawati pada tahun 2011 yang dieksekusi pada tahun 2018 di Arab Saudi, hal ini jelas melanggar Pasal 3 Universal Declaration of Human Rights karena telah mengambil nyawa seseorang bahkan eksekusi dilakukan tanpa pemberitahuan kepada pemerintah Indonesia.

Eleanor Rooselvelt dan Rene Cassin, dua di antara para perumus Universal Declaration of Human Rights, mengatakan bahwa hak untuk hidup itu tak mengenal pengecualian, dan tujuan pasal hak untuk hidup itu adalah agar

\footnotetext{
${ }^{6}$ Ekho J.P. Nalole, Tinjauan Hukum Internasional Terhadap Pelaksanaan Hukuman Mati Bagi Warga Negara Asing di Indonesia (Studi Kasus Eksekusi Mati terhadap Warga Negara Asing pada Awal Masa Pemerintahan Presiden Joko Widodo dan Wakil Presiden Muhammad Jusuf Kalla), (Makassar: 2016), hal. 41
} 
kelak hukuman mati itu bisa dihapuskan. Sesungguhnya makna "non-derogable human rights" itu dimulai dengan sikap Roosevelt dan Cassin yang tegas tentang hak untuk hidup. Tetapi ICCPR masih memiliki ruang untuk hukuman mati terutama di negara-negara yang masih menjatuhkan hukuman mati pada "the most serious crimes" terutama yang berkaitan dengan kejahatan genosida dan kejahatan terhadap kemanusiaan. Hanya saja kalau dibaca keseluruhan Pasal 6 ICCPR, kita akan melihat bahwa hak untuk hidup adalah semangat yang utama yang harus terus dihormati sampai nanti dia betul-betul menjadi hak asasi yang absolut yang sifatnya "non-derogable" dalam keadaan apa pun. ${ }^{7}$

Berdasarkan penjelasan di atas, hukuman mati atau yang sering disebut dengan pidana mati bertentangan dengan ketentuan internasional hak asasi manusia terutama Pasal 3 UDHR yaitu hak untuk hidup. Namun terdapat pengecualian dari Pasal tersebut yaitu Pasal 4 ayat (1) ICCPR 'derogable right' yang pada intinya hukuman mati dapat dilaksanakan dengan kualifikasi kejahatan tersebut membahayakan publik. ${ }^{8}$

b) Hukuman Mati menurut International Covenant on Civil and Political Rights

International Covenant on Civil and Political Rights (ICCPR) merupakan kovenan internasional yang berisi mengenai hak-hak sipil dan politik dari setiap individu. Kovenan ini disetujui oleh Majelis Umum Perserikatan Bangsa-Bangsa pada 16 Desember 1966.

Hukuman mati merupakan jenis pelanggaran hak asasi manusia yang paling penting, dikarenakan hak untuk hidup (right to life) seseorang. Hak fundamental (nonderogable rights) ini merupakan jenis hak yang tidak bisa dilanggar, dikurangi, atau dibatasi dalam keadaan apapun, baik itu dalam keadaan darurat, perang, termasuk bila seseorang menjadi narapidana.

Walaupun Kovenan Internasional Hak Sipil dan Politik tidak secara langsung menyatakan bahwa hukuman mati melanggar hak hidup

\footnotetext{
7 Lubis, Santosa \& Maramis Law Firm, 2006, http://www.Ismlaw.co.id/index.php?option=com_content \&view=article\&id=206\%3Ainkonstitutionalitas-hukumanmati\&catid=49\%3Aarticles\&ltemid=18\&lang=en, diakses pada 4 desember 2019

8 Lihat Pasal 4 ayat (1) International Covenant on Civil and Political Rights
}

atau pun hak yang lain, namun sebagian ahli dan beberapa pengadilan menyatakan bahwa hukuman mati melanggar hak hidup. Hukuman mati (pada dasarnya pembunuhan berencana juga) merupakan sesuatu yang amat berbahaya bila yang bersangkutan tidak bersalah. Tidaklah mungkin diadakan suatu perbaikan apapun bila orang sudah dipidana mati.

Dalam pasal 6 International Covenant on Civil and Political Rights :

1. Every human being has the inherent right to life. This right shall be protected by law. No one shall be arbitrarily deprived of his life.

2. In countries which have not abolished the death penalty, sentence of death may be imposed only for the most serious crimes in accordance with the law in force at the time of the commission of the crime and not contrary to the provisions of the present Covenant and to the Convention on the Prevention and Punishment of the Crime of Genocide. This penalty can only be carried out pursuant to a final judge ment rendered by a competent court.

3. When deprivation of life constitutes the crime of genocide, it is understood that nothing in this article shall authorize any State Party to the present Covenant to derogate in any way from any obligation assumed under the provisions of the Con vention on the Prevention and Punishment of the Crime of Genocide.

4. Anyone sentenced to death shall have the right to seek pardon or commuta tion of the sentence. Amnesty, pardon or commutation of the sentence of death may be granted in all cases.

5. Sentence of death shall not be imposed for crimes committed by persons below eighteen years of age and shall not be carried out on pregnant women.

6. Nothing in this article shall be invoked to delay or to prevent the abolition of capital punishment by any State Party to the present Covenant ${ }^{9}$.

Yang dalam bahasa Indonesia diterjemahkan :

1. Setiap manusia berhak atas hak untuk hidup yang melekat pada dirinya. Hak ini

9 Pasal 6 International Covenant on Political and Civil Rights 
wajib dilindungi oleh hukum. Tidak seorangpun dapat dirampas hak hidupnya secara sewenang-wenang.

2. Di negara-negara yang belum menghapuskan hukuman mati, putusan hukuman mati hanya dapat dijatuhkan terhadap kejahatan-kejahatan yang paling serius sesuai dengan hukum yang berlaku pada saat dilakukannya kejahatan tersebut, dan tidak bertentangan dengan ketentuanketentuan ini dan Konvensi tentang Pencegahan dan Penghukuman terhadap kejahatan Genosida. Hukuman ini hanya dapat dilaksanakan atas dasar keputusan akhir yang dijatuhkan oleh suatu pengadilan yang berwenang.

3. Apabila suatu perampasan kehidupan merupakan kejahatan Genosida, harus dipahami bahwa tidak satupun dalam pasal ini memberikan kewenangan pada Negara Pihak pada Konvenan ini untuk mengurangi kewajiban-kewajiban apapun yang telah dibebankan oleh ketentuan Konvensi tentang Pencegahan dan Penghukuman Kejahatan Genosida.

4. Setiap orang yang dijatuhi hukuman mati harus mempunyai hak untuk memohon pengampunan atau pengurangan hukuman mati dapat diberikan kepada semua kasus.

5. Hukuman mati tidak boleh dijatuhkan atas kejahatan yang dilakukan seseorang di bawah usia delapan belas tahun, dan tidak boleh dilaksanakan terhadap perempuan hamil.

6. Tidak ada ketentuan dalam pasal ini yang boleh dipakai untuk menunda atau mencegah penghapusan hukuman mati oleh negara Pihak pada Kovenan ini.

Pasal 6 ayat (1) menegaskan bahwa setiap pada setiap manusia melekat hak untuk hidup. Hak ini harus dilindungi oleh hukum. Tidak ada seorang pun manusia yang boleh dirampas hidupnya. Pelaksanaan eksekusi mati ini telah melanggar Pasal 6 ayat (1) yang pada dasarnya eksekusi mati menimbulkan kesakitan fisik dan dirampasnya hak untuk hidup seseorang.

Pasal 6 ayat (2) mengecualikan pemberian hukuman mati dapat diberikan kepada pelaku kejahatan yang paling serius atau kejahatan luar biasa. Hukuman mati masih banyak diterapkan di berbagai Negara. Antara lain Indonesia dan juga Arab Saudi, yang menjadi permasalahannya ialah tidak adanya pemenuhan dan pengaturan yang jelas terhadap pelaksanaan hukuman mati tersebut baik dalam proses penangkapan maupun dalam pelaksanaan pemeriksaan di persidangan, sehingga hal tersebut bertentangan dengan konsep the rule of law dimana terdapatnya pengaturan yang jelas baik itu persamaan kedudukan dihadapan hukum dan juga terdapatnya peradilan yang bebas dan tidak memihak yang berimplikasi kekuasaan kehakiman yang merdeka. ${ }^{10}$ Dengan demikian, sekalipun hukuman mati diperbolehkan asalkan diatur berdasarkan hukum nasional, namun hukum tersebut haruslah sah (legal), adil (just), dapat dijadukan pegangan dan masuk akal (reasonable).

Pasal 6 ayat (4) seseorang yang telah dihukum mati harus mempunyai hak untuk memohon pengampunan atau keringanan hukuman. Amnesty pengampunan atau keringanan hukuman mati dapat diberikan dalam segala hal.

Selanjutnya dalam Pasal 6 ayat (5) dengan jelas hukuman mati tidak dapat diberikan pada wanita yang sedang mengandung mau pun anak berusia di bawah delapan belas tahun, dikarenakan penjatuhan hukuman mati bagi wanita yang sedang mengandung sama saja dengan membunuh bayi dalam kandungan yang juga memiliki hak untuk hidup. Sedang, penjatuhan hukuman mati bagi anak di bawah delapan belas tahun, dianggap kejahatan yang dilakukan oleh anak di bawah delapan belas tahun bukanlah keinginan dari orang tersebut, tetap dapat dipicu oleh lingkungan bahkan yang terburuk karena kelalaian orang tua.

c) Hukuman Mati menurut Second Optional Protocol to the International Covenant on Civil and Political Rights

Protokol opsional kedua kovenan internasional tentang hak-hak sipil dan politik ini khusus ditujukan pada penghapusan hukuman mati. Protokol opsional kedua ini

\footnotetext{
10 Ekho J.P. Nalole, Tinjauan Hukum Internasional Terhadap Pelaksanaan Hukuman Mati Bagi Warga Negara Asing di Indonesia (Studi Kasus Eksekusi Mati terhadap Warga Negara Asing pada Awal Masa Pemerintahan Presiden Joko Widodo dan Wakil Presiden Muhammad Jusuf Kalla), (Makassar: 2016), hal. 43
} 
merupakan perjanjian tambahan untuk Kovenan Internasional tentang Hak-hak Sipil dan Politik. Perjanjian tersebut dirumuskan pada 15 Desember 1989, dan mulai berlaku pada 11 Juli 1991. Tercatat Protokol Opsional Kedua ini memiliki 86 negara anggota hingga bulan September tahun 2018 lalu.

Semua upaya penghapusan hukuman mati akan dianggap sebagai kemajuan dalam menikmati hak atas penghidupan. Para Negara Peserta dalam Protokol ini telah setuju untuk menetapkan Protokol Optional Kedua pada Kovenan Internasional tentang Hak-hak Sipil dan Politik, yang Ditujukan pada Penghapusan Hukuman Mati.

Protokol ini mewajibkan negara yang meratifikasinya (state parties) menghapuskan eksekusi dan hukuman mati dalam legislasi maupun praktiknya. Kondisi saat ini, sekitar 140 negara di dunia sudah menghapuskan hukuman mati atau kalaupun tidak menghapuskan, tapi sudah tidak mempraktikkannya lagi. Sisanya, 58 negara, termasuk Indonesia, masih memberlakukan hukuman mati dalam sistem peradilan pidananya. ${ }^{11}$

Second Optional Protocol mendalilkan perlunya hukuman mati dihapus, dengan merujuk pada Pasal 3 Deklarasi Universal HAM (Universal Declaration of Human Rights) yang berbunyi: "Setiap orang memiliki hak untuk hidup, hak atas kebebasan, dan hak atas keamanan (life, liberty, and security of person), juga pada Pasal 6 Kovenan Internasional tentang Hak-Hak Sipil dan Politik (International Covenant on Civil and Political Rights ICCPR) yang berbunyi: "Setiap orang mempunyai hak yang tak terpisahkan dan dilindungi oleh hukum, yaitu hak untuk hidup." 12

d) International Criminal Tribunal for the former Yugoslavia (ICTY) dan International Criminal Tribunal for Rwanda (ICTR)

ICTY (International Criminal Tribunal for the former Yugoslavia) dan ICTR (International Criminal Tribunal for Rwanda) adalah dua Mahkamah Kejahatan Internasional ad-hoc

11 https://www.republika.co.id/berita/koran/opinikoran/15/01/22/nikh4m-menimbang-hukuman-mati, diakses pada 28 november 2019, 03.41am

12 https://referensi.elsam.or.id/2014/09/protokoloptional-kedua-pada-kovenan-internasional-tentang-hakhak-sipil-dan-politik-yang-ditujukan-pada-penghapusanhukuman-mati/ diakses pada 28 November 2019, pukul $03.43 \mathrm{am}$ yang dibentuk pada tahun 1990-an. Meskipun tidak secara eksplisit terdapat gagasan yang kuat didalam statuta ICTY dan ICTR untuk menolak penerapan pidana mati. Artikel 24 Statuta ICTY dan Artikel 23 ICTR menegaskan bahwa "the penalty imposed by the trial chamber shall be limited to Imprisonment" ini berarti bahwa didalam 46 sistem peradilan ICTY dan ICTR, pidana mati tidak akan diterapkan. Dapat diartikan bahwa para pelaku Genosida, pelaku kejahatan perang, dan pelaku kejahatan terhadap kemanusiaan, termasuk yang terwujud dalam tindakan-tindakan penyiksaan, eksperimen biologis dalam perang, penyanderaan penduduk sipil, pengeboman desa-desa yang bukan merupakan objek militer dalam perang, perbudakan, pembunuhan, penyiksaan dan perkosaan sampai kapanpun tidak akan pernah dipidana mati dibawah sistem ICTY dan ICTR. ${ }^{13}$

e) International Criminal Court (ICC)

International Criminal Court (ICC) Mahkamah Pidana Internasional adalah pengadilan tetap dan independen pertama yang mampu melakukan penyelidikan dan mengadili setiap orang yang melakukan pelanggaran terberat terhadap hukum kemanusiaan internasional, seperti kejahatan perang, kejahatan kemanusiaan, pembunuhan dan tindakan agresi. ${ }^{14}$

Mahkamah Pidana Internasional didirikan berdasarkan Statuta Roma 1998 yang merupakan suatu konfrensi diplomatik yang berlangsung di Roma pada tanggal 15-17 juli 1998. Menurut Pasal 4 ayat (1) statuta Roma, Mahkamah Pidana Internasional memiliki kepribadian hukum internasional (international legal personality). Hal ini berarti, bahwa Mahkamah Pidana Internasional berkedudukan sebagai subjek hukum internasional dengan kemampuannya memiliki hak-hak dan memikul kewajiban- kewajiban berdasarkan hukum internasional dalam ruang lingkup tugas dan kewenangannya serta maksud dan tujuannya.

13 Ekho J.P. Nalole, Tinjauan Hukum Internasional Terhadap Pelaksanaan Hukuman Mati Bagi Warga Negara Asing di Indonesia (Studi Kasus Eksekusi Mati terhadap Warga Negara Asing pada Awal Masa Pemerintahan Presiden Joko Widodo dan Wakil Presiden Muhammad Jusuf Kalla), (Makassar: 2016), hal. 45

14 Simon, S.H., Mengenal ICC Mahkamah Pidana Internasional, (Jakarta Pusat: Sentralisme Production, 2009) hal.3 


\section{B. Tanggung Jawab Negara Indonesia terhadap Pelaksanaan Hukuman Mati Tuti Tursilawati di Arab Saudi dikaitkan dengan Hukum Internasional}

Upaya perlindungan hak-hak asasi manusia mendorong penghapusan hukuman mati sehingga berkembang dalam masyarakat internasional. Penghapusan hukuman mati dilihat sebagai suatu elemen yang penting dalam perkembangan demokrasi di negaranegara yang ingin memutuskan hubungan dengan masa lalu yang dipenuhi dengan teror, ketidakadilan dan penindasan. Tren penghapusan ini terlihat dari berbagai produk hukum internasional yang dibentuk guna mendorong penghapusan hukuman mati. Sebagaiamana yang sudah kita bahas di atas Universal Declaration of Human Rights (Deklarasi Universal Hak Asasi Manusia) dan International Covenant on Civil and Political Rights (Kovenan Internasional Hak Sipil dan Politik) merupakan instrumen hukum hak asasi manusia yang paling mendasar serta beberapa konvensi regional lainnya.

Berdasarkan upaya perlindungan Hak Asasi Manusia yang merupakan tujuan dari Perserikatan Bangsa-bangsa, Majelis Umum Perserikatan Bangsa-Bangsa mengeluarkan resolusi "Moratorium on the Use of the Death Penalty" yang menghimbau penghapusan hukuman mati.

Pada tahun 2007, sudah 142 negara yang menghapus hukuman mati (abolisi), sedangkan 55 negara masih menerapkan pelaksanaan hukuman mati.

Perserikatan Bangsa-bangsa mengeluarkan panduan dalam konteks sipil dan politik (bagi Negara yang masih menerapkan praktik hukuman mati) yang berjudul "Safeguards Guaranteein Protection of the Rights of Those Facing the Death Penalty (Jaminan Perlindungan bagi Mereka yang mengahadapi Hukuman Mati)". ${ }^{15}$ Ketentuan yang dikeluarkan tersebut terus diperbaharui seiring dengan perkembangan yang ada. Panduan ini

\footnotetext{
15 Lihat United Nations Human Rights office of the high commissioner, 1996-2019, https://www.ohchr.org/EN/Professionallnterest/Pages/De athPenalty.aspx, diakses pada 19 November 2019, pukul $08.19 \mathrm{am}$
}

memperjelas pembatasan praktik hukuman mati menurut Kovenan Sipil dan Politik.

Di negara yang belum menghapuskan hukuman mati, penerapannya hanya bisa berlaku bagi kejahatan yang paling serius yang, yang kategorinya harus sesuai dengan tingkat konsekuensi yang sangat keji.

Hukuman mati hanya boleh berlaku bila kejahatan tersebut tercantum dalam produk hukum tertulis yang tidak bersifat retroaktif/berlaku surut pada saat kejahatan tersebut dilakukan dan jika di dalam produk hukum tersebut tersedia hukum yang lebih ringan, maka yang terakhir ini yang harus diterapkan.

Hukuman mati tidak boleh diterapkan pada anak berusia 18 tahun pada saat ia melakukan kejahatan tersebut. Hukuman mati tidak boleh di terapkan pada perempuan atau ibu yang baru melahirkan. Hukuman mati tidak boleh dijatuhkan kepada orang cacat mental atau gila. Hal-hal ini dikarenakan kejahatan oleh anak di bawah umur bisa terjadi karena dipicu oleh lingkungan tidak semata-mata merupakan keinginan anak tersebut. Sedangkan untuk perempuan atau ibu yang sedang mengandung, hukuman mati dapat berarti juga membunuh anak dalam kandungan yang mana anak tersebut sudah memiliki hak untuk hidup. Juga, kejahatan yang dilakukan oleh orang cacat mental atau gila bukanlah sesuatu kejahatan yang dilakukan secara sadar, sehingga hukuman mati tidaklah pantas untuk diberikan.

Hukuman mati hanya boleh diterapkan ketika kesalahan si pelaku sudah tidak menyediakan sedikitpun celah yang meragukan dari suatu fakta atau kejadian. Hal ini mencegah terjadinya salah tangkap dan eksekusi.

Hukuman mati hanya bisa dijatuhkan sesuai dengan keputusan hukum yang final lewat sebuah persidangan yang kompoten yang menjamin sebuah prinsip fair trial. Paling tidak sesuai dengan Pasal 14 Kovenan Internasional Hak-hak Sipil dan Politik, termasuk pada setiap kasus yang diancam hukuman mati, setiap terdakwa harus disediakan pembelaan hukum yang memadai seperti keharusan seorang terdakwa didampingi pengacara dan penterjemah bahasa bila ia disidang dalam bahasa yang tidak ia mengerti. Terdakwa juga harus disediakan akses terhadap informasi yang lengkap atas persidangan tersebut. 
Seseorang yang dijatuhkan hukuman mati berhak untuk mengajukan pengampunan, atau perubahan hukuman. Hal ini harus mencakup semua jenis kejahatan.

Hukuman mati tidak boleh diberlakukan untuk membatalkan upaya pengajuan pengampunan atau perubahan hukum.

Ketika eksekusi mati dijalankan, cara penghukumannya harus seminimal mungkin menimbulkan penderitaan. ${ }^{16}$

Bagi Negara yang masih menerapkan hukuman mati, hukuman harus diberikan dengan alasan yang jelas, yang mana sanksi diberikan karena sudah tidak ada lagi sanksi yang dapat digunakan, atau bersifat Ultimum Remedium. Eksekusi baru boleh dilakukan kalau semua upaya hukum sudah dilakukan. Sayangnya, praktik hukuman mati banyak sekali dilakukan tanpa upaya hukum yang maksimal.

Sistem hukum di Arab Saudi memang berbeda dengan Negara lain. Terlebih lagi jika hukum tersebut menyangkut dengan eksekusi mati. Tidak hanya Indonesia, beberapa Negara lain pun kesulitan jika warga negaranya berurusan dengan Arab Saudi. Arab Saudi menerapkan sistem hukum Islam, yang berdasarkan pada Alquran dan hukum mereka juga memberlakukan hukum Had, Ta'zir dan Qishash, yaitu hukuman mati terhadap pembunuh, hukuman itu harus dibayar dengan nyawa, dengan cara dipancung. Masalah ini pun sebenarnya sudah menjadi kepedulian di dunia internasional.

Tuti Tursilawati berangkat ke Arab Saudi pada tahun 2009 sebagai TKI. la bekerja di kota Thaif, sebagai penjaga lansia selama 8 bulan dengan keterangan sisa gaji tak di bayar selama 6 bulan.

Berdasarkan laman Serikat Buruh Migran Indonesia, Tuti ditangkap kepolisian Arab Saudi pada 12 Mei 2010 atas tuduhan membunuh ayah majikannya, Suud Mulhaq Al Utaibi. Tuti ditangkap sehari setelah kejadian pembunuhan. Sejak ditangkap dan ditahan pihak kepolisian, Konsulat Jenderal RI Jeddah melalui satgasnya di Thaif, Said Barawwas, memberikan pendampingan dalam proses investigasi awal di kepolisian. Kemudian, Said Barawwas juga mendampingi proses investigasi lanjutan di Badan Investigasi.

16 Ibid, Hal.28-29
Selama proses investigasi, Tuti Tursilawati mengakui pembunuhan ayah majikannya. Ia beralasan sering mendapatkan pelecehan seksual dan kekerasan. Apa yang dilakukannya adalah pembelaan diri.

Kementerian Luar Negeri mencatat ada 103 WNI yang terancam hukuman mati di Arab Saudi pada 2011 hingga 2018. Sebanyak 85 WNI di antaranya berhasil dibebaskan, 5 orang lainnya dieksekusi mati oleh pihak Arab Saudi dan masih ada 13 WNI yang terancam dieksekusi mati pada tahun 2018.

Berdasarkan Piagam PBB Pasal 1 angka (1), yang menjadi tujuan PBB yaitu untuk memelihara perdamaian dan keamaan internasional, dan untuk tujuan itu : mengadakan tindakan-tindakan bersama yang efektif untuk mencegah dan melenyapkan ancaman-ancaman terhadap pelanggaranpelanggaran terhadap perdamaian, dan akan menyelesaikan dengan jalan damai, serta sesuai dengan prinsip-prinsip keadilan dan hukum internasional, mengatur atau menyelesaikan pertikaian-pertikaian internasional atau keadaan-keadaan yang dapat mengganggu perdamaian, ${ }^{17}$ dari tujuan itu PBB tidak memiliki kewenangan dalam hal memberi sanksi terhadap sikap Arab Saudi yang sudah menghukum mati warga Negara Indonesia tanpa notifikasi, PBB hanya bisa mengecam Arab Saudi jika tindakan tersebut sudah terjadi secara besar-besaran atau genosida, akan tetapi hal ini pun bertentangan dengan sistem hukum di Arab Saudi yang menjunjung dan menerapkan hukum Islam. Dalam hal ini yang lebih akan berperan adalah pemerintah Indonesia yang bertanggung jawab atas keselamatan Warga Negaranya.

Setiap Negara memiliki hak untuk melindungi dan memelihara eksistensinya dalam masyarakat internasional. Akan tetapi, hak tersebut sama sekali tidak menyiratkan adanya pembenaran tindakan Negara untuk melindungi serta memelihara eksistensinya melalui tindakan yang bertentangan dengan hukum internasional. ${ }^{18}$

Pertanggungjawaban Negara dapat didefinisikan sebagai pertanggungjawaban yang

\footnotetext{
17 Pasal 1 Piagam Perserikatan Bangsa-bangsa

18 Dr. FX. Adji Samekto, SH, MH, Negara dalam dimensi Hukum Internasiona, (Bandung: PT. Citra Aditya Bakti, 2009)
} 
dibebankan kepada suatu Negara karena tindakan Negara tersebut yang telah melakukan tindakan yang merugikan Negara lain. ${ }^{19}$

Agar suatu peristiwa dapat dikategorikan akan menimbulkan pertanggungjawaban Negara, maka ada unsur-unsur yang harus dipenuhi, yaitu sebagai berikut:

a) Adanya suatu tindakan yang tidak sesuai dengan hukum internasional atau tidak dikehendaki oleh pihak Negara yang dirugikan.

b) Adanya kerusakan atau kerugian yang diderita dari pihak Negara lain..

Unsur lain yang harus dipenuhi adalah tindakan tersebut harus dapat dilimpahkan pertanggungjawabannya kepada Negara. Menurut Komisi Hukum Internasional dalam laporannya tentang pertanggungjawaban Negara pada tahun 1973, tindakan yang dapat dilimpahkan kepada Negara adalah:

a) Tindakan organ Negara dalam kapasitas resmi jabatan

b) Tindakan organ-organ yang bukan Negara merupakan bagian dari struktur formal pemerintah, melainkan diberi kekuasaan secara sah untuk melakukan tugas-tugas pemerintah

c) Tindakan perorangan atau sekelompok individu yang bertindak atas nama Negara atau dalam kenyataannya melaksanakan tindakan-tindakan pemerintah dalam ketiadaan penguassa resmi, dan di dalam situasi yang membenarkan situasi yang membenarkan aktivitas-aktivitas tersebut.

Negara tidak dapat menghindari tanggung jawab Negara dengan alasan bahwa organorgan negaranya telah bertindak melebihi wewenangnya (ultra vires) dari yang telah ditentukan dalam hukum nasionalnya. ${ }^{20}$

Dasar Deklarasi Universal Hak Asasi Manusia (UDHR) dan Kovenan Internasional Hak Sipil dan Politik (ICCPR) pun tidak dapat membantu karena UDHR ditantang oleh Negara dengan sistem hukum Islam dan ICCPR hanya ditanda tangani oleh 76 negara, dan Arab Saudi tidak termasuk di dalamnya.

Keprihatinan terhadap proses hukum di Arab Saudi ini pun menjadi keresahan bagi

19 Ibid

20 Ibid, hal 104-105 pemerintah Indonesia dalam kasus Tuti Tursilawati, yang merupakan Tenaga Kerja Indonesia (TKI) di kerajaan tersebut.

Kementrian Luar Negeri, Iqbal mengatakan pemerintah telah melakukan berbagai upaya untuk meringankan hukuman. Kementrian Luar Negeri juga sudah berkunjung sebanyak 47 kali ke penjara Tuti sejak 2011.

Permohonan peninjauan kembali terhadap kasus Tuti sempat dikabulkan oleh pengadilan di Arab Saudi. Pemerintah pun mengupayakan pembebasan terhadap Tuti. Akan tetapi, pada Oktober Tuti Tursilawati dieksekusi mati, tanpa pembertihuan.

Kasus yang menimpa Tuti Tursilawati ternyata bukan kali pertama terjadi di Indonesia. Data dari Migrant Care menyebutkan bahwa eksekusi hukuman mati tanpa nofifikasi seperti Tuty sudah terjadi lima kali dalam 10 tahun terakhir. Terhitung sejak tahun 2008, ada lima WNI lainnya yang mengalami hal serupa selain Tuti. Menurut catatan Migrant Care, $72 \%$ pekerja migran yang menghadapi hukuman mati adalah perempuan. Tuti sendiri telah menjalani proses hukuman yang cukup lama, yakni sekitar tujuh tahun.

Pemerintah Indonesia sudah melayangkan protes terhadap sikap Pemerintah Arab Saudi yang dianggap tidak memiliki adab atau etika politik diplomasi dengan mengeksekusi mati buruh migran asal Indonesia tanpa notifikasi terlebih dahulu.

Perlindungan bagi setiap warga negara merupakan kewajiban yang harus dipenuhi oleh suatu negara. Hal ini berlaku di mana pun dia berada, bahkan seluruh penjuru dunia, karena perlindungan yang diberikan merupakan salah satu hak warga Negara. Begitu juga negara Indonesia yang wajib melindungi setiap warga negaranya di mana mereka berada. Hal ini sesuai dengan Pembukaan Undang-Undang Dasar Negara Republik Indonesia Tahun 1945 (UUD Negara Republik Indonesia Tahun 1945) Alinea ke 4 (empat), dan dinyatakan pula dalam Batang Tubuh UUD Negara Republik Indonesia Tahun 1945 Pasal 28D ayat (1) yang menyatakan bahwa "Setiap orang berhak atas pengakuan, jaminan, perlindungan, dan kepastian hukum yang adil serta perlakuan yang sama di hadapan hukum". ${ }^{21}$ Oleh karena

\footnotetext{
21 Undang-undang Dasar 1945
} 
itu dengan adanya perlindungan warga Negara Indonesia di manapun dia berada, negara bukan hanya memenuhi kewajibannya namun juga telah memenuhi hak asasi manusia warga negara tersebut.

Dalam konteks Hak Asasi Manusia, negara menjadi subjek hukum utama, karena negara merupakan entitas utama yang bertanggung jawab melindungi, menegakkan, dan memajukan hak asasi manusia, setidaknya untuk warga negaranya masing-masing. Pelanggaran HAM biasanya justru dilakukan oleh negara, baik secara langsung melalui tindakan-tindakan yang termasuk pelanggaran HAM terhadap warga negaranya atau warga negara lain, maupun secara tidak langsung melalui kebijakan-kebijakan ekonomi politik baik di level nasional maupun internasional yang berdampak pada tidak terpenuhinya atau ditiadakannya HAM warga negaranya atau warga negara lain. ${ }^{22}$

Negara dianggap melakukan pelanggaran berat HAM (gross vilence of human rights) jika :

a) Negara tidak berupaya melindungi atau justru meniadakan hak-hak warganya yang digolongkan sebagai non-derogable rights; atau

b) Negara yang bersangkutan membiarkan terjadinya atau justru melalui aparataparatnya tindakan kejahatan internasional (international crimes) atau kejahatan serius (seriouse crimes) yaitu kejahatan genosida, kejahatan terhadap kemanusiaan dan kejahatan perang; dan/atau negara tersebut gagal atau tidak mau menuntut pertanggungjawaban dari para aparat negara pelaku tindak kejahatan tersebut. ${ }^{23}$

Berdasarkan instrument-instrumen Hak Asasi Manusia internasional, telah diterima bahwa pihak yang terikat secara hukum dalam pelaksanaan HAM adalah negara. Dalam konteks ini, negara berjanji untuk mengakui, menghormati, melindungi, memenuhi, dan menegakkan HAM. Ketentuan hukum HAM tersebut memberi penegasan pada hal-hal berikut ini:

22 Anonim, https://Isc.bphn.go.id/artikel?id=365, diakses pada 19 november 2918, pukul 08.26 am.

$23 \mathrm{lbid}$ a) Negara sebagai pemangku tanggung jawab (duty holder), yang harus memanuhi kewajiban-kewajibannya dalam pelaksanaan HAM baik secara nasional maupun internasional, sedangkan individu dan kelompokkelompok masyarakat adalah pihak pemegang hak (right holder)

b) Negara tidak memiliki hak, negara hanya memikul kewajiban dan tanggung jawab (obligation and responsibility) untuk memenuhi hak warga negaranya (baik indivisu maupun kelompok) yang dijamin dalam instrument-instrumen HAM internasional.

c) Jika negara tidak mau atau tidak punya keinginan untuk memenuhi kewajiban dan tanggung jawabnya, pada saat itulah negara tersebut bisa dikatakan telah melakukan pelanggaran HAM atau hukum internasional. ${ }^{24}$

Jika pelanggaran tersebut tidak mau dipertanggungjawabkan oleh negara, maka tanggung jawab itu akan diambil alih oleh masyarakat internasional. Sebagai pihak yang memangku tanggung jawab, negara dituntut harus melaksanakan dan memenuhi semua kewajiban yang dikenakan kepadanya secara sekaligus dan segera. Jika kewajiban-kewajiban tersebut gagal untuk dilaksanakan maka negara akan dikatakan telah melakukan pelanggaran. Ada dua jenis pelanggaran yang bisa terjadi berkaitan dengan pelaksanaan kewajiban dan tanggung jawab negara, yaitu:

a) Pelanggaran karena tindakan (by commission) terjadi karena negara justru malah melakukan tindakan langsung untuk turut campur dalam mengatur hakhak warga negara yang semestinya dihormati.

b) Pelanggaran karena pembiaran (by omission) terjadi ketika negara tidak melakukan sesuatu tindakan atau gagal untuk mengambil tindakan lebih lanjut yang diperlukan untuk melaksanakan kewajiban hukum. ${ }^{25}$

Berdasarkan kasus Tuti Tursilawati, Negara Indonesia sudah menjalankan tanggung jawab dalam upaya melindungi Hak Asasi Manusia warga negaranya. Tidak ada pelanggaran yang

$24 \mathrm{Ibid}$ 
dilakukan Indonesia terkait dengan tanggung jawab Negara dalam melindungi warga negaranya. Indonesia tidak melakukan pembiaran terhadap warga Negaranya yang dijatuhi hukuman mati di Arab Saudi itu. Sebaliknya, Indonesia sudah mengambil tindakan tepat dalam pendampingan hukum kepada Tuti, bahkan dalam berbagai cara.

Direktur Perlindungan WNI Kementrian Luar Negeri yang lalu, Muhammad Iqbal mengatakan, hukuman mati yang dijatuhkan kepada Tuti Tursilawati tergolong hukuman mati mutlak atau had gillah. Had gillah merupakan hukuman mati tertinggi di Arab Saudi, setelah Qishash dan Ta'Zir, karena tidak bisa diampuni oleh raja, atau ahli waris korban. Tindakan yang termasuk Had gillah hanya dapat dimaafkan oleh Allah SWT. Dalam kasus Had, apabila vonis yang dijatuhkan sudah berstatus inkracht (berkekuatan hukum tetap), maka pemerintah tidak mempunyai hak untuk memaafkan pelaku. ${ }^{26}$ Tuti tetap tidak bisa lolos dari hukuman mati karena vonis yang ditetapkan padanya sudah berkekuatan hukum tetap.

\section{PENUTUP}

\section{A. Kesimpulan}

1. Dalam perjuangan melindungi hak-hak asasi manusia, hukum internasional sudah mengupayakan penghapusan hukuman mati yang masih saja diterapkan di berbagai Negara. Upaya perlindungan Hak Asasi Manusia ini dapat dilihat dari usaha-usaha penghapusan hukuman mati oleh hukum internasional yang dituangkan dalam berbagai instrumen hukum internasional dan dalam statute-statutta Mahkamah Internasional. Walaupun instrumeninstrumen hukum ini tidak secara eksplisit melarang hukuman mati, tetapi bersamaan dengan beberapa additional protocols yang secara tegas melarang hukuman mati, hukum hak asasi manusia internasional telah menunjukkan konsistensi dalam tujuan implisit yaitu mewujudkan penghapusan total di kemudian hari.

2. Pelaksanaan hukuman mati terhadap Tuti Tursilawati merupakan tanggung jawab Negara Indonesia. Pemerintah Indonesia sudah berusaha untuk melakukan perlindungan bagi warga negaranya. Hal ini merupakan kewajiban yang harus dipenuhi oleh Negara Indonesia, berlaku di mana pun warga negaranya berada. Pemerintah Indonesia juga sudah melayangkan protes kepada pemerintah Arab Saudi karena telah mengeksekusi Tuti Tursilawati tanpa pemberitahuan. $\mathrm{Hal}$ ini menggerakkan pemerintah Indonesia yang dengan segera meminta Arab Saudi untuk menandatangani perjanjian Mandatory Consular Notification.

\section{B. Saran}

1. Dampak dari instrumen hukum internasional yang masih bersifat additional dan optional mengenai hukuman mati, membuat beberapa Negara masih saja memberlakukan dan menerapkan hukuman mati. Saran penulis terhadap produk hukum internasional yang berupa instrumen yang masih bersifat additional atau optional dapat diubah menjadi instrument yang bersifat mandatory atau amending, agar bisa mengambil posisi yang lebih jelas dalam hal pengaturan hukuman mati.

2. Karena tidak adanya Mandatory Consular Notification, Arab Saudi dengan sewenang-wenang mengeksekusi mati Tuti Tursilawati tanpa pemberitahuan pada tahun 2018 setelah dijatuhi hukuman sejak tahun 2010. Saran penulis, agar pemerintah Indonesia harus segera mendesak kembali Arab Saudi untuk menandatangi Mandatory Consular Notifcation agar tak ada lagi eksekusi mati tanpa pemberitahuan, mengingat masih ada warga Negara Indonesia yang ditahan di penjarapenjara di sana.

\section{DAFTAR PUSTAKA}


Djamali R. Abdoel, Pengantar Hukum Indonesia, Edisi Revisi, Rajawali Pers, Jakarta, 2014

Heliarta, Mengenal Hukum Internasional, Loka Aksara, Tangerang, 2019

Parthiana I Wayan, Ekstradisi dalam Hukum Internasional dan Hukum Nasional, Penerbit Alumni, Bandung, 1983

Samekto Adji, Negara dalam dimensi Hukum Internasional, PT. Citra Aditya Bakti, Bandung, 2009

Simon, Mengenal ICC Mahkamah Pidana Internasional, Sentralisme Production, Jakarta Pusat 2009

Starke J. G., Pengantar Hukum Internasional, PT.Sinar Grafika, Jakarta, 2010

Sujatmoko Andrey, Hukum HAM dan Hukum Humaniter, PT RajaGrafindo Persada, Jakarta, 2015

Tiara Ayu Eza, Pengaturan Hukuman Mati di Beberapa Negara, Jakarta, 2016

Tunggal Hadi Setia, Perserikatan Bangsabangsa dan Hak-hak Asasi Manusia, Harvarindo, Jakarta , 2000

Jurnal

Ekho Jamaluddin P. Nalole, Tinjauan Hukum Internasional Terhadap Pelaksanaan Hukuman Mati Warga Negara Asing di Indonesia, Makassar, 2016

M. Cherif Bassiouni, International Criminal Law Volume I: Crimes, Transnational Publisher Inc, New York, 1986

Martin Dixon, Textbook on International Law, 6th ed.,Oxford University Press, United States, 2007

Nowak, M., U.N. Covenant on Civil and Political Rights CCPR Commentary, 2nd revised edition, N.P.Engel, Publishers, 2005

\section{Internet}

https://www.academia.edu/5484392/PEMBAH ASAN_EXTRAORDINARY_CRIMES

https://reformasikuhp.org/kejahatan-genosidakejahatan-terhadap-kemanusiaan-dankejahatan-perang-dalam-r-kuhp-2015/

https://icjr.or.id/mengenal-kovenaninternasional-hak-sipil-dan-politik/ https://www.bbc.com/indonesia/indonesia46030543

https://tesishukum.com/pengertian-hukuminternasional-menurut-para-ahli/ https://www.gurupendidikan.co.id/hukumpidana-internasional-pengertiankarakteristik-dan-sumber-beserta-asasasasnya-secara-lengkap/

https://www.tagar.id/tujuh-jenis-hukumanmati-masih-berlaku-saat-ini

https://www.republika.co.id/berita/koran/opin i-koran/15/01/22/nikh4m-menimbanghukuman-mati

https://referensi.elsam.or.id/2014/09/protokol -optional-kedua-pada-kovenaninternasional-tentang-hak-hak-sipildan-politik-yang-ditujukan-padapenghapusan-hukuman-mati/

https://lsc.bphn.go.id/artikel?id=365

Pebriansyah Ariefana,

https://www.suara.com/news/2018/10/31/140 502/3-jenis-hukum-pidana-islam-arab-saudisemua-hukuman-mati 